\title{
Promoting mobile collaborative language learning in Islamic higher education
}

\author{
Rully Agung Yudhiantara \\ rully.agung@uinsgd.ac.id \\ English Education Department, Faculty of Tarbiyah and Teacher Training, \\ Universitas Islam Negeri Sunan Gunung Djati Bandung, Indonesia \\ Jalan A.H. Nasution No. 105, Cipadung, Cibiru, Kota Bandung, Jawa Barat 40614, \\ Indonesia
}

\section{Ade Yeti Nuryantini}

adeyetin@gmail.com

Physics Education Department, Faculty of Tarbiyah and Teacher Training, Universitas Islam Negeri Sunan Gunung Djati Bandung, Indonesia

Jalan A.H. Nasution No. 105, Cipadung, Cibiru, Kota Bandung, Jawa Barat 40614, Indonesia

Received: September 28, 2018;

Accepted: March 1, 2019;

Published: March 9, 2019

\begin{abstract}
This study sought to explore students' experience in using Instagram to participate in mobile collaborative language learning (MCLL). The contents they produced and shared, as well as their interaction and collaboration, were analyzed. The participants of this study were 110 students in an English education department, in three different classes, who all had taken a translation course their third semester. Online tasks were assigned to students and they were required to produce, share, interact and collaborate to accomplish tasks. This study applied a qualitative method with case study research design using observation, focus group discussion and content analysis. Data were analyzed through stages namely categorization, reduction and interpretation. Results showed that the students were able to participate in MCLL using Instagram. They produced and shared contents that met the requirement of MCLL. The contents included English sentences for structural collaboration in terms of subject-verb agreement and English sentences for word meaning collaborations. They interacted with their peers by writing feedback and comments on the Journal on English as a Foreign Language, 9(1), 87-106 Copyright $@ 2019$ by JEFL, p-ISSN 2088-1657; e-ISSN 2502-6615
\end{abstract}


uploaded content. They collaborated with their peers by providing multiple interactions to accomplish tasks in MCLL like writing structural analysis, word meaning, paraphrasing sentences, and sentence translation.

Keywords: English pre-service teachers; mobile collaborative language learning (MCLL); mobile-assisted language learning (MALL); Instagram; social media

How to cite this paper: Yudhiantara, R. A., \& Nuryantini, A. Y. (2019). Promoting mobile collaborative language learning in Islamic higher education. Journal on English as a Foreign Language, 9(1), 87-106. doi:http://dx.doi.org/10.23971 ßefl.v9i1.961

DOI: http://dx.doi.org/10.23971 ßefl.v9i1.961

The advancement of information and communication technology (ICT) has inspired many foreign language teaching experts and practitioners to develop language learning and teaching like flipped learning (Fauzan \& Ngabut, 2018). An ICT like a smartphone offers students benefits that are available from its features and applications facilitating language learning both in the classroom and beyond (Kukulska-Hulme \& Shield, 2008). On the part of Students, direction and training on the use of mobile devices to support their language learning process need to be addressed. As stated by Yudhiantara and Nasir (2017), when smartphone use for language learning is properly tailored, students may reap many features and benefits to support English language learning both in the classroom and beyond its wall.

Mobile assisted language learning (MALL) has been a burning issue among foreign language teachers especially EFL teachers. MALL opens an opportunity for teachers who are digital immigrants, to explore smartphone features for their students in learning a foreign language. Language teachers have found possible benefits from mobile devices compared to a fixed desktop computer in boosting students' motivation and performance. MALL studies such as conducted by Kukulska-Hulme and Shield (2008) focused on possibilities, benefits, challenges, motivation and the effect of mobile devices used to support foreign language learning. Its publication as a topic of interest in EFL is well documented before 2006 regarding student perceptions, the use of several tools for language learning, and the dominance of English for foreign language learning using mobile devices (Shadiev, Hwang, \& Huang, 2017). 
MALL includes a number of electronic devices for information and communication in language learning. These gadgets have been examined for their potential benefits in language learning. iPod has been used for learning German language conversation and facilitating interaction and scaffolding (Lys, 2013). Additionally, Lin, Huang, and Liou (2013) assert that Tablet computers have also proven to be an ideal learning tool for creating content and collaborating since they can be operated anytime and anywhere by language learners. Other mobile devices like cell phones and tablets support many foreign language learning activities both in class and out of class (Arvanitis, Krystalli, \& Panagiotidis, 2016).

For youths and teenagers, the most widely used gadget is a mobile phone. Compared to other devices, a mobile phone caters to their need to search for information and communicate with their peers. In an educational context, according to Wang and Smith (2013), this tool helps them to learn reading and grammar as it provides a great experience in their language learning. It not only helps students to accomplish the task of searching and communicating with friends in a foreign language for an educational purpose, but also serves as an additional tool to a laptop device while they complete this simple task (Vasudeva, Colthorpe, \& Ernst, 2017). Furthermore, its existing applications benefit students by helping them deal with language components. In other words, students have a powerful device to navigate and explore and to support English learning- related activities (Yudhiantara \& Saehu, 2017).

A mobile phone is closely related to social media applications for youth, especially students. Social media is the most prominent category of applications used by teenagers who are digital natives glued to their gadgets and who spend most of their time navigating social media (Prensky, 2001). It is an application that can both be used to interact and share content at the same time with other users. Godwin-Jones (2005) stated that this platform attracts language education experts who are interested in conducting studies on the potential and benefits of social media for foreign language learning. The top three social media applications which are used worldwide by millions are Facebook, Twitter, and Instagram.

The most popular social media applications have been investigated by language researchers for their promising benefits in language learning. Facebook, according to Özdemir (2017), has been investigated for its ability to promote intercultural communicative competence. This social media has inspired language researchers and teachers to integrate its power in foreign

Journal on English as a Foreign Language, 9(1), 87-106

Copyright ( 2019 by JEFL, p-ISSN 2088-1657; e-ISSN 2502-6615 
language learning since it provides space for students to participate and interact for the purpose of language development (Warner, 2017), and supports students in online interaction by expressing their social presence and interacting to discuss taught material in the classroom (Arnold \& Ducate, 2006). Other applications which have gained more and more users because of their useful features are Twitter and Instagram. The former can be designed to facilitate English language learning using the feature of micro blogging (Yudhiantara, 2017), and to trigger better learning discussions among students beyond a classroom because they can share material, interact and reflect on their foreign language learning (Chawinga, 2017). In addition, as stated by Liliia and Gulnara (2016), the latter can be tailored to help students learn listening comprehension since it features video content to share among users.

With the growth of ICT and internet use among language teachers and researchers, the issue of online participation and multimodal content sharing come into existence. According to Satar \& Akcan (2018), the development of Web-based learning can support face-to-face learning and also improve students' online interaction skills. Its development brings more advantages of an opportunity for students to produce content in a digital form which provide a wider autonomous space for language learners. The content and product students create can be in so-called multimodal formats. The term multimodal is an emerging one referring to the sharing of various file types such as audio, video, and texts. Moreover, multimodal content can be created by language learners to accomplish their learning activities and the products can be studied by language researchers (Blake, 2016).

Students need to improve their skills that are crucial in the $21^{\text {st }}$ century for them to strive to meet future challenges. One of the skills they need to harness is collaboration. Given the rapid development of mobile phone use and internet expansion, the notion of online collaboration in language classes has attracted researchers and practitioners. To achieve online collaboration in a language class, a teacher may assign tasks or a project to be accomplished by students individually or in a group. The assignments and project groups can be done online using their mobile phone to provide opportunities for students to conduct collaborative language learning online (Paulus, 2005). In the context of English language learning, teachers need to use several approaches that enable language learners to produce target language in order to accomplish tasks and projects. 
In a collaborative language learning context, students should be assigned a task allowing them to collaborate to accomplish it. A task or project can be designed for language learners to accomplish using their mobile phone. Students may use their mobile phone to both communicate with their peers using an application and to accomplish the task at the same time through their participation and interaction online. According to Kukulska-Hulme and Viberg (2018), these practices have been growing in language classes and published in various journals under the scope of mobile collaborative language learning Social media has the power in terms of features to offer both language teachers and learners the chance to implement mobile collaborative language learning (MCLL). Language learners can explore social media features to communicate with their peers and interact to create a particular content meeting the requirement of a particular task given by their teacher. Their interaction using social media can boost their performance to produce a completed task and accomplish MCLL (Lee, 2016). In addition, social media platform has the power to facilitate interaction and collaboration among students to complete the task in MCLL (Sun, Liu, Luo, Wu, \& Shi, 2017).

In the context of social media use for language learning, the interaction between users can be categorized into several types. Participation, interaction, and collaboration are the types that may appear in social media in the context of English learning. In its simple explanation, the three types seem like a sequence for interaction. Students should participate first to show to other users their presence. Their presence can initiate other users to interact for educational purposes. The collaboration stage can happen when students have gone through the first two stages, that is participation and interaction (Hara, Bonk, \& Angeli, 2000).

Social media has the ability to facilitate online participation, interaction and collaboration on the part of language learners. These three types of communication can be demonstrated by their participation in social media. Moreover, their high interaction with other students signals a strong effort on the part of students to complete a group project or task. Also, their interaction can be seen from comment and messages available in their thread and these data are open to access and exploration by language teachers (Sing \& Khine, 2006).

In response to the growing concern with online participation research, several studies have been conducted on the topic. The studies cover online interaction to supplement students' class discussion in an effort to accomplish 
their group assignment (Hara et al., 2000); pattern and type of collaborative interaction between pre-service teacher and language teachers (Pawan, Paulus, Yalcin, \& Chang, 2003); collaborative dialogue to accomplish task (Paulus, 2005); online interaction to support students' independence and reduce teachers' dominance in the classroom (Zheng \& Warschauer, 2015); and, metaanalysis on articles published to investigate conversational analysis (Paulus, Warren, \& Lester, 2016).

Types of online interaction can be defined more specifically. First, participation refers to a message sent in a discussion without any peer response. Second, the interaction can occur when a sent message gets feedback from other peers. In this stage, there is no response to the feedback from the sender of the message or from other colleagues. The last sequence, collaboration, happens when interaction is plural. As stated by Zhao, Sullivan, and Mellenius (2014), it is said that the sender of the message gets more peer feedback from other colleagues and in addition, the sender sends feedback to maintain interaction.

MCLL using social media, particularly Instagram, has been reported by language researchers. Instagram is popular among social media users including students and is easy to integrate to their language learning. This platform makes it possible to create, send and share content among students. Al-Ali (2014) mentions that this application serves as a mobile learning tool that facilitates students' learning of English, especially writing skills, even when they are on vacation Furthermore, for the purpose of learning English, this social media plays a pivotal role in nurturing an online educational environment which assists students in learning English language skills (Liliia \& Gulnara, 2016). In addition, it has several features that can be geared toward English learning. The video feature may facilitate speaking skill learning and the comment thread can be designed for writing skill learning (Handayani, 2016).

Language researchers have not paid special concern to Instagram and its use to promote MCLL in Indonesia, especially in an Islamic higher education context. This research tries to fill the void of literature on MCLL with the assistance of Instagram among students in Islamic higher education. It is an effort to seize the benefits of mobile- assisted language learning (MALL) which is geared toward nurturing students' skills; namely, communication and collaboration, both crucial in the $21^{\text {st }}$ century. Other benefits include preparing students to be able to integrate technology to enhance their language learning 
and nurturing them to produce content which is suitable for language learning purposes.

Based on the objective of this study, there were several questions it sought to explore: 1) how do students use Instagram to participate in MCLL?; 2) what content is produced and shared by students on Instagram?; and 3) how do students interact and collaborate with their group in an attempt to accomplish MCLL?

\section{METHOD}

This research applied qualitative methods to investigate Instagram use to support MCLL among students of an English education department in an Islamic higher education context. Case study research design was used to explore the student's experience. Specifically, the study aimed to investigate their Instagram use, the content produced and shared, and interaction and collaboration in order to accomplish MCLL.

The subjects were 110 second-year students in the English Education Department, Faculty of Tarbiyah and Teacher Training, Universitas Islam Negeri (UIN) Sunan Gunung Djati Bandung. There were three classes and all students took the Translation II Course. This course was aimed at equipping them with the theory, knowledge, and skills to translate Indonesian text into English.

Data were collected by giving participants tasks to accomplish and then observing their activities. There were 4 types of tasks. Each was designed for Instagram and aligned to the objectives of the Translation II course. This study adopted research steps for online collaboration (Paulus, Woodside, \& Ziegler, 2008).

Data were collected from participants several times as the course proceeded. There were four tasks that students needed to accomplish. They used their mobile phone to produce content and shared it using their Instagram account. In addition, they interacted and collaborated on the content to accomplish the tasks. In a nutshell, these activities demonstrated their experience in MCLL.

Data obtained from this research were analyzed in several stages: data descriptions, data categorization, data coding, and interpretation. In addition, 
this study applied content analysis for English pre-service teachers interaction and collaboration on Instagram (Hara et al., 2000).

\section{FINDINGS}

This study investigated students' experience in using Instagram to participate in MCLL; to produce and share content produced, to interact and collaborate to produce content to accomplish tasks. The findings of the study will be organized into three sections to answer the research questions.

\section{Instagram Use to Participate in MCLL}

Based on observations, this study obtained some data concerning students' participation using Instagram. Students took the course and they were introduced to the notion of Instagram use for language learning. Focus group discussion was also conducted to investigate their knowledge of Instagram and the use of it in their daily life. Having undergone a training session, they also learned to use Instagram to support MCLL and finally worked with their group to accomplish tasks. It is shown in Table 1.

Table 1. Sequences of Students' Participation in Using Instagram to Support MCLL

\begin{tabular}{cll}
\hline No & \multicolumn{1}{c}{ Activity } & \multicolumn{1}{c}{ What Students did } \\
\hline 1 & $\begin{array}{l}\text { Discussion on social media } \\
\text { Instagram }\end{array}$ & $\begin{array}{l}\text { Students Exchanged experiences and opinions } \\
\text { on Instagram use in their daily life }\end{array}$ \\
\hline 2 & $\begin{array}{l}\text { Discussion on Instagram } \\
\text { use for the purpose of } \\
\text { language learning }\end{array}$ & $\begin{array}{l}\text { Students discussed the possibility of using } \\
\text { Instagram to facilitate language learning }\end{array}$ \\
\hline 3 & $\begin{array}{l}\text { Learning to use Instagram } \\
\text { for language learning }\end{array}$ & $\begin{array}{l}\text { Students learned how to integrate Instagram for } \\
\text { language learning by exploring features and } \\
\text { options available in Instagram }\end{array}$ \\
\hline 4 & $\begin{array}{l}\text { Instagram Use to } \\
\text { accomplish MCLL }\end{array}$ & $\begin{array}{l}\text { Students practiced using Instagram to interact } \\
\text { and collaborate with their group to produce } \\
\text { content to accomplish MCLL }\end{array}$ \\
\hline
\end{tabular}

From Table 1, it can be seen that the process of students' participation in using Instagram to accomplish MCLL underwent several stages, each with its own activity on the part of students.

In a focus group discussion, students exchanged their experiences and opinion on Instagram use in their daily life. Most of them explored and enjoyed Instagram to share their photos. They agreed that the core function of this social 
media is photo sharing. Some of them also used it to share their daily activities, hobbies, and their achievements.

When it came to discussion of the possibility of using Instagram to facilitate language learning, there were several findings. The notion of Instagram use for language learning was not familiar to most of the students. They were aware that they could access several sources for English learning on Instagram. They mentioned several newspapers, TV stations and influential people saying that Instagram had benefits for language learning. On the other hand, they did not have the experience of how Instagram could be used to support their classroom activities.

In a focus group discussion, students discussed what features available in Instagram could support language learning. They learned how to integrate Instagram for MCLL in their translation course. They agreed that video and photo content offered by Instagram might facilitate language learning. In addition, the caption feature could improve writing skills. They were ready to use those features of Instagram to conduct group work and produce content to accomplish MCLL.

Students applied their new knowledge and skills. They worked on several tasks given to them. Using Instagram with their group, they interacted and collaborated on a variety of content. They produced content to meet the demand of MCLL.

\section{Content Produced and Shared on Instagram to Accomplish MCLL}

Having investigated students' knowledge and experience using Instagram for MCLL, This study sought to explore the content that they had produced and shared as shown.

Table 2 shows that the students uploaded and shared their content to meet the requirement of MCLL. The first type of content is related to the English structure. They selected their sentence and took a photo of it. Their content was shared on their own account. In the caption section, they invited their peers to analyze sentence structure available in their shared content.

The second kind of content that students produced and shared refers to word meaning or definition. For this, they shared a photo containing an underlined word from a particular sentence. In the caption section, they asked their friends to contribute to the word's definition. 
Table 2. Content Produced and Shared by Students to Accomplish Tasks in MCLL

\begin{tabular}{|c|c|c|c|c|}
\hline $\mathrm{No}$ & \multicolumn{3}{|c|}{ Content } & \multirow[b]{2}{*}{$\begin{array}{l}\text { What Students Accomplished } \\
\text { Using hashtag } \\
\text { \#mall2018translation, } \\
\text { students labeled their } \\
\text { contents that they submitted } \\
\text { using Instagram so that their } \\
\text { content can be organized to } \\
\text { make their search easier. }\end{array}$} \\
\hline 1 & 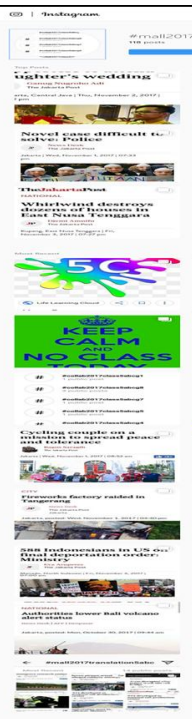 & 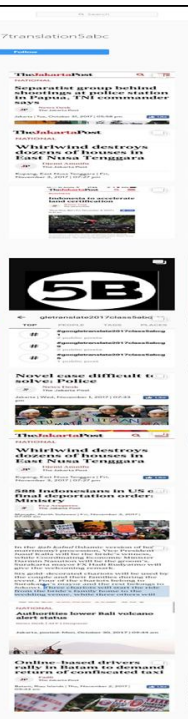 & 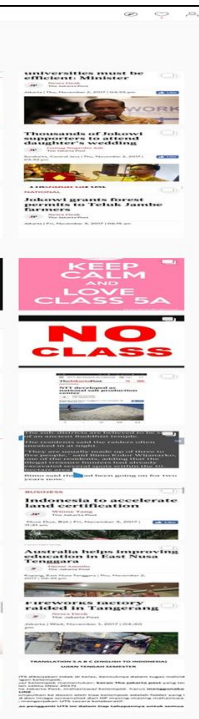 & \\
\hline \multirow[t]{2}{*}{2} & (1) | mistagram & $\operatorname{cosen} x$ & (2) ? & \multirow[b]{2}{*}{$\begin{array}{l}\text { Using hashtag } \\
\text { \#googletranslate2018, } \\
\text { students shared their content } \\
\text { on the use of Google } \\
\text { Translate to transfer the } \\
\text { source language to target } \\
\text { language. }\end{array}$} \\
\hline & 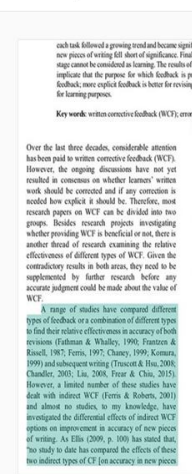 & 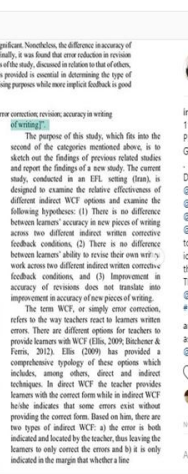 & 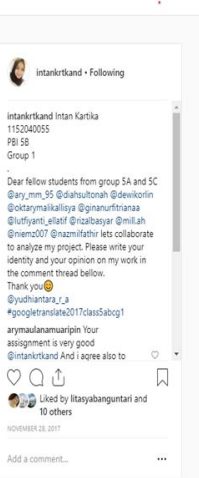 & \\
\hline
\end{tabular}

Journal on English as a Foreign Language, 9(1), 87-106

Copyright @ 2019 by JEFL, p-ISSN 2088-1657; e-ISSN 2502-6615 


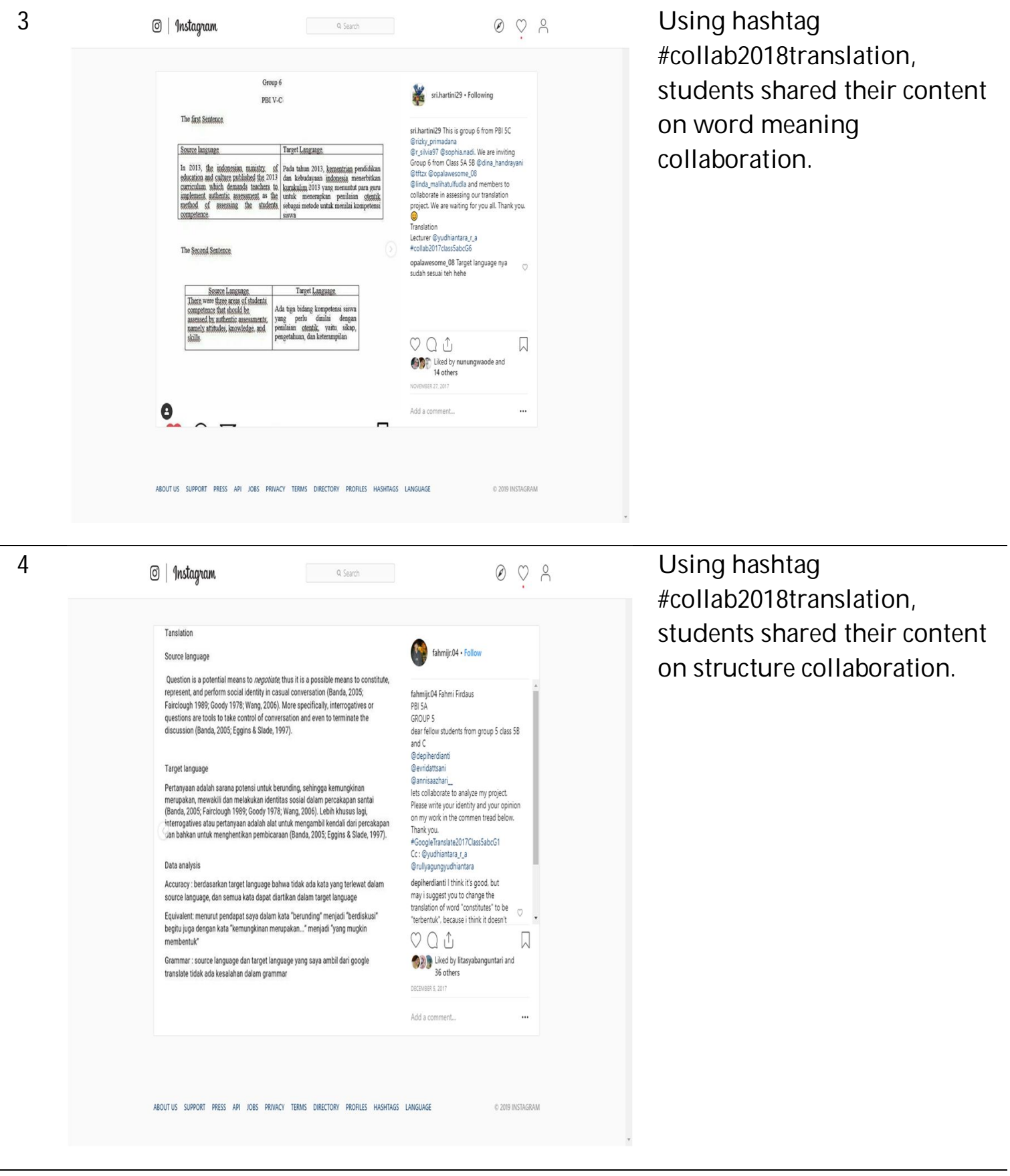

The types of content shared to show how students used Instagram to fulfill MCLL. Shared content allowed interaction and collaboration to happen among students. This happened because there was a need to collaborate to jointly solve the English sentence problem in terms of its structure. Similarly, with word meaning, interaction and collaboration occurred among students to solve the problem.

Journal on English as a Foreign Language, 9(1), 87-106

Copyright ( 2019 by JEFL, p-ISSN 2088-1657; e-ISSN 2502-6615 
This content clearly shows how Instagram provided space for students to create and share images and captions for the purpose of language learning. It goes without saying that the main function of Instagram is photo or images sharing and students used this function for language learning- related content.

\section{Interaction and Collaboration among Students in Instagram to Accomplish MCLL}

The last type of data collected in this study is related to the interaction and collaboration that occurred between students and their collaborative friends. Table 3 shows how students used Instagram for collaborative language learning purposes.

Table 3. Interaction and Collaboration among Students in Instagram to Produce Content to Accomplish MCLL

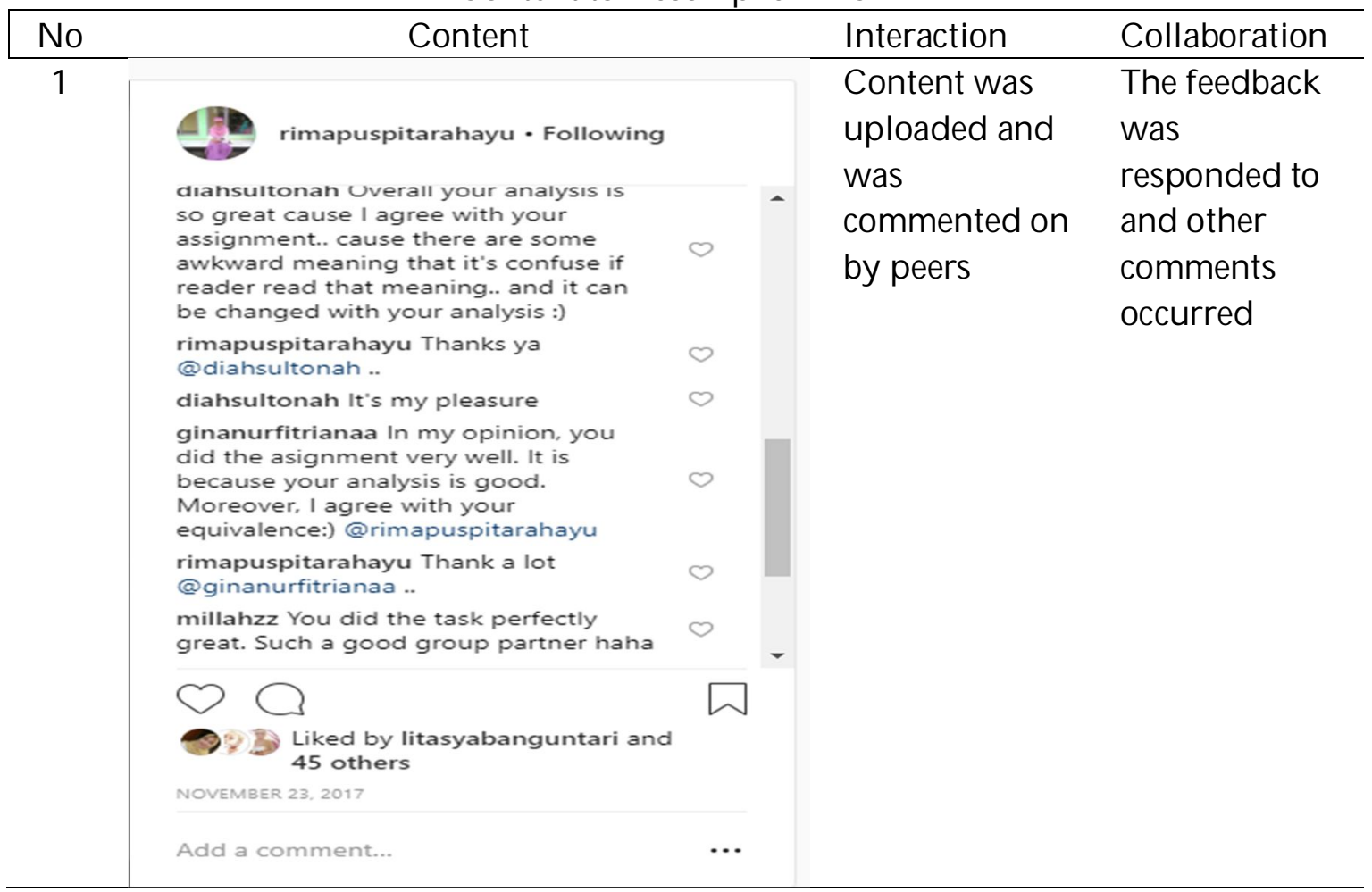

Journal on English as a Foreign Language, 9(1), 87-106

Copyright $@ 2019$ by JEFL, p-ISSN 2088-1657; e-ISSN 2502-6615 


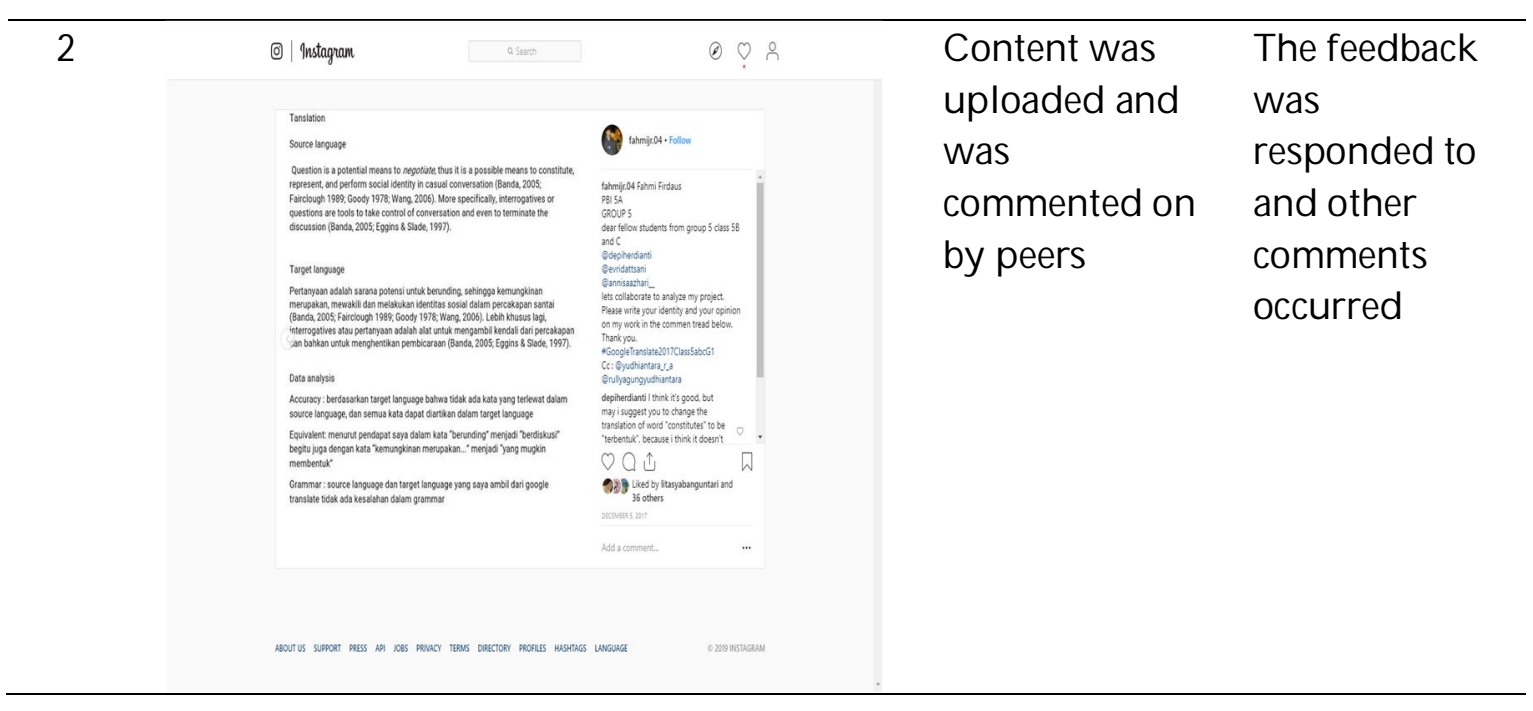

From Table 3, it is shown that the students interacted with their group members to discuss content shared by each student. For example, for paraphrasing sentences, they uploaded the sentence to get feedback from their collaborative friends. This shows the interaction between the content sender and his collaborative partner through Instagram social media happened.

\section{DISCUSSION}

This study falls into the category of research on MALL trends in EFL teaching and learning (Kukulska-Hulme \& Shield, 2008). It investigated students' experience in using Instagram for MCLL in an Islamic higher education context. A previous study by Yudhiantara and Nasir (2017) showed that in Islamic higher education institutions, a mobile phone is a daily need for students and if properly tailored, it can support English language learning. Students in this study agreed that their mobile phone was the most frequently used gadget in their daily life. In their opinion, compared to other gadgets, a mobile phone excels in term of communication and information delivery (Wang \& Smith, 2013). They also agreed that a mobile phone offered them easy access to language learning, anywhere or anytime.

With respect to research question one, the findings of this study show that students could participate in MCLL for the Translation II course. They had the ability to use Instagram to support the educational need to complete the course tasks. This is in line with previous research findings on students' ability to use Instagram (Liliia \& Gulnara, 2016) both in the classroom and outside the classroom in order to exchange information for language learning purposes (Handayani, 2016). Various efforts need to be made to improve students' 
learning process in translation courses (Rahmawati \& Hakim, 2018). One such effort is to offer social media for MCLL. In this study, students used Instagram not only for searching content from other accounts, but also created and shared their own content suitable to fulfill their language learning needs. This finding confirms a previous study by Özdemir (2017) that suggests social media can be tailored to support language learning.

Regarding research question two, students exhibited an ability to create content and interact with their peers to collaborate on particular content. Their interaction and collaboration were made possible by Instagram. Social media can be used by students to interact and share content among their peers. This finding is in line with previous studies' claims that social media offers an opportunity for language learning (Godwin-Jones, 2005), potential and benefit for the purpose of language development (Warner, 2017), and intercultural communicative competence learning (Özdemir, 2017).

Students not only produced and shared content but also showcased it in a multimodal way. They shared content in the form of video, images, and captions. Such content can be called multimodal. Their content was designed by combining the sharing of file types such as audio and video texts that can be studied by language learners (Yeh, 2018). Hafner and Miller (2011) argue that to produce the content, students needed to spend their effort, creativity, and other literacies and combine them to apply multi-literacies to produce a particular content using social media.

Concerning research question three, this study found that students interacted and collaborated with their peers. Using Instagram, they produced content to accomplish tasks in MCLL. A social media platform has the power to facilitate interaction and collaboration among students to complete the task (Abrams, 2016). Collaboration occurred through Instagram. As stated by Paulus (2005), social media provides opportunities for students to conduct MCLL. English learning needs to use several approaches that enable learners to produce authentic foreign language according to the needs, time and real context of life. The design of task-based language learning allows students to simultaneously use language while completing tasks.

Students uploaded content which fulfilled the requirements of the translation course tasks. The content they created and shared was a way to enhance their interaction with other collaborating friends. This is a benefit that students can gain in MCLL using Instagram. This finding is in line with the 
previous studies reporting that social media can facilitate interaction (Zheng \& Warschauer, 2015); can support students' online interaction by expressing their social presence and interacting to discuss taught material in the classroom (Arnold \& Ducate, 2006); and, can trigger better learning discussions among students beyond the classroom because they can share material, interact and reflect on their foreign language learning (Chawinga, 2017).

This study found that students produced and shared content calling for peer response, which ensured interaction took place. For example, a student shared content asking his peers to provide comment where paraphrasing should be addressed. This ensures interaction and it invites peer feedback. As stated by Sing and Khine (2006), continuous interactions can be increased and these comments are good indicators of online collaboration. Such interaction using social media can boost students' performance to produce a task (Abrams, 2016). In addition to interaction among peers, this study found students collaborated. Their collaboration could be seen from the number of comments made about particular content. Collaboration happens when interaction is plural. This is to say that the sender of the message gets more peer feedback from other colleagues and in addition the sender sends feedback to maintain interaction. As confirmed by Zhao et al. (2014), more interaction brings more chance for collaboration. A large number of comments from a collaborative friend helps the task gets done right away. The contribution of many comments will give input to students completing their tasks (Hara et al., 2000). In addition, providing comment and receiving comment in an online interaction may support students' independence and reduce teachers' dominance in the classroom (Zheng \& Warschauer, 2015).

\section{CONCLUSION}

This study was aimed at exploring Instagram use among students to participate in MCLL in a translation course. Having discussed the findings above, this study offers several conclusions. First, students were able to use Instagram to participate in MCLL. Their knowledge on Instagram uses helped them to integrate social media for the purposes of language learning. They showed their ability to bring Instagram to the next level, i.e. for MCLL purposes.

Second, content was produced and shared by students to accomplish tasks in MCLL. There were several types of content produced and shared in their Instagram account namely: word meaning, sentence structure analysis, 
sentence translation. These required multi-literacies to enable them to make and combine ideas using files and skills they had.

Third, interaction and collaboration in Instagram were carried out by students to accomplish tasks in MCLL. They used Instagram thread comments to seek further comments and interaction with their peers in order to accomplish tasks in MCLL. Their interaction and collaboration can be seen from the comment thread in their Instagram accounts which was open to access by other users to read and comment; the contents produced and shared by students met the criteria of MCLL.

This study is limited by the method used so the findings may not be generalized for other contexts. Further studies should address this issue using a different method. The more studies conducted on MALL issues the better for

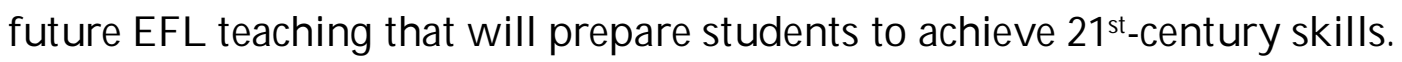

\section{REFERENCES}

Abrams, Z. (2016). Exploring collaboratively written L2 texts among first-year learners of German in Google Docs. Computer Assisted Language Learning, 29(8), 1259-1270. https://doi.org/10.1080/09588221.2016.1270968

Al-Ali, S. (2014). Possible use of Instagram as a language learning tool. Issues and Trend in Educational Technology, 2(2), 1-16.

Arnold, N., \& Ducate, L. (2006). Future foreign language teachers' social and cognitive collaboration in an online environment. Language Learning $\mathcal{E}$ Technology, 10(1), 42-66. https://doi.org/10.1111/.19449720.2005.tb02227.x

Arvanitis, P., Krystalli, P., \& Panagiotidis, P. (2016). Applications for mobile assisted language learning: A current field research. Proceedings of INTED2016 Conference 7th-9th March 2016, Valencia, Spain, (December 2017), 7645-7651. https://doi.org/10.21125/inted.2016.0803

Blake, R. (2016). Technology and the four skills. Language Learning E Technology, 20(202), 129-142. Retrieved from http://lt.msu.edu/issues/june2016/blake.pdf

Chawinga, W. D. (2017). Taking social media to a university classroom: teaching and learning using Twitter and Blogs. International Journal of Educational Technology in Higher Education, 14(1). 
https://doi.org/10.1186/s41239-017-0041-6

Fauzan, A., \& Ngabut, M. N. (2018). EFL students' perception on flipped learning in writing class. Journal on English as a Foreign Language, 8(2), 115. https://doi.org/10.23971 ßefl.v8i2.792

Godwin-Jones, R. (2005). Emerging technologies: Messaging, gaming, peer-topeer sharing: Language learning strategies \& tools for the millennial generation. Language Learning \& Technology, 9(1), 17-22. Retrieved from http://lt.msu.edu/vo19num1/pdf/vol9num1.pdf\#page=24\%5Cnhttp://ww w.questia.com $/$ M.qst?a=o\&se $=$ gglsc $\& d=5008329079$

Hafner, C. A., \& Miller, L. (2011). Fostering learner autonomy in English for science: A collaborative digital video project in a technological learning environment. Language Learning $\mathcal{E}$ Technology, 15(3), 68-86. Retrieved from http://lt.msu.edu/issues/october2011/hafnermiller.pdf

Handayani, F. (2016). Instagram as a teaching tool? Really? In Proceedings of the Fourth International Seminar on English Language and Teaching (ISELT-4) ISELT-4 (pp. 320-327).

Hara, N., Bonk, C. J., \& Angeli, C. (2000). Content analysis of online discussion in an applied educational psychology course. Instructional Science, 28(2), 115-152. https://doi.org/10.1023/A:1003764722829

Kukulska-Hulme, A., \& Shield, L. (2008). An overview of mobile assisted language learning: From content delivery to supported collaboration and interaction. $\quad \operatorname{ReCALL}, \quad 20(03), \quad 271-289$. https://doi.org/10.1017/S0958344008000335

Kukulska-Hulme, A., \& Viberg, O. (2018). Mobile collaborative language learning: State of the art. British Journal of Educational Technology, 49(2), 207-218. https: //doi.org/10.1111/bjet.12580

Lee, L. (2016). Autonomous learning through task-based instruction in fully online language courses. Language Learning E Technology, 20(2), 81-97. Retrieved from http://lt.msu.edu/issues/june2016/lee.pdf

Liliia, K., \& Gulnara, G. (2016). Instagram : Mobile application in teaching EFL at university level mobile technologies in teaching English as a foreign language in higher education: A case study of using. In ICERI 2016 Proceedings 9th International Conference of Education, Research and 
Innovation November 14th-16th, 2016

https://doi.org/10.21125/iceri.2016.0395

Lin, Huang, \& Liou. (2013). The effects of text-based SCMC on SLA: A metaanalysis. Language Learning \& Technology, 17(2), 123-142. Retrieved from http://lt.msu.edu/issues/june2013/inetal.pdf

Lys, F. (2013). the Development of advanced learner oral proficiency using Ipads. Language Learning $\mathcal{E}$ Technology, 17(173), 94-116. Retrieved from http://lt.msu.edu/issues/october2013/yss.pdf

Özdemir, E. (2017). Promoting EFL learners' intercultural communication effectiveness: a focus on Facebook. Computer Assisted Language Learning, 30(6), 510-528. https://doi.org/10.1080/09588221.2017.1325907

Paulus. (2005). Collaborative and cooperative approaches to online group work: The impact of task type. Distance Education, 26(1), 111-125. https://doi.org/10.1080/01587910500081343

Paulus, T., Woodside, M., \& Ziegler, M. (2008). Extending the conversation: Qualitative research as dialogic collaborative process. Qualitative Report, 13(2), 226-243. Retrieved from http://ssaweb110v.csa.com/ids70/view_record.php?id=3\&recnum $=96 \& l o$ $\mathrm{g}=$ from_res\&SID=7ndsl0lqpq9t0qbm6m905dier3\&mark_id=search:3:97,90 ,100

Paulus, Warren, A., \& Lester, J. N. (2016). Applying conversation analysis methods to online talk: A literature review. Discourse, Context and Media, 12(2013), 1-10. https://doi.org/10.1016/.dcm.2016.04.001

Pawan, F., Paulus, T. M., Yalcin, S., \& Chang, C.-F. (2003). Online learning: Patterns of engagement and interaction among in-service teachers. Language Learning \& Technology, 7(3), 119-140.

Prensky, M. (2001). Digital natives, digital immigrants part 2: Do they really think differently? On the Horizon, 9(6), 1-6. https://doi.org/10.1108/10748120110424843

Rahmawati, M., \& Hakim, P. K. (2018). The influence of e-portfolio toward the process and the quality of students' translation. Journal on English as a Foreign Language, 8(2), 202-218.

Satar, H. M., \& Akcan, S. (2018). Pre-service EFL teachers' online participation, Journal on English as a Foreign Language, 9(1), 87-106

Copyright $\odot 2019$ by JEFL, p-ISSN 2088-1657; e-ISSN 2502-6615 
interaction, and social presence. Language Learning $\mathcal{E}$ Technology, 22(1), 157-183.

Shadiev, R., Hwang, W. Y., \& Huang, Y. M. (2017). Review of research on mobile language learning in authentic environments. Computer Assisted Language Learning, 30(3-4), 284-303. https://doi.org/10.1080/09588221.2017.1308383

Sing, C. C., \& Khine, M. S. (2006). An analysis of interaction and participation patterns in Online community. Educational Technology E Society, 9(1), 250261.

Sun, Z., Liu, R., Luo, L., Wu, M., \& Shi, C. (2017). Exploring collaborative learning effect in blended learning environments. Journal of Computer Assisted Learning, 33(6), 575-587. https://doi.org/10.1111/jcal.12201

Vasudeva, Colthorpe, \& Ernst. (2017). Student-initiated mobile learning in higher education. In 16th World Conference on Mobile and Contextual Learning.

Wang, S., \& Smith, S. (2013). Reading and grammar learning through mobile phones. Language Learning \& Technology, 17(3), 117-134.

Warner, C. (2017). Designing talk in social networks: What Facebook teaches about conversation. Language Learning $\mathcal{E}$ Technology Blattner $\mathcal{E}$ Fiori Reinhardt \& Ryu Language Learning $\mathcal{E}$ Technology, 21(212), 121-138. Retrieved from http://lt.msu.edu/issues/june2017/warnerchen.pdf

Yeh, H. (2018). Exploring the perceived benefits of the process of multimodal video making in developing multiliteracies. Language Learning $\mathcal{E}$ Technology Blattner $\mathcal{E}$ Fiori Reinhardt $\mathcal{E}$ Ryu Language Learning $\mathcal{E}$ Technology, 22(2), 28-37. https: //doi.org/10.125/44642

Yudhiantara, \& Nasir. (2017). Toward mobile-assisted language learning (MALL): Reaping mobile phone benefits in classroom activities. Register Journal, 10(1), 12-28. https://doi.org/DOI: http://dx.doi.org/10.18326/rgt.v10i1.12-28 ENGLISH

Yudhiantara, R. A. (2017). Twitter for educational activities in Islamic higher education, why not? IJET, 6(1), 89-101. Retrieved from http://ijet.uinsby.ac.id/index.php/jurnalpbi/article/view ß8/pdf_18

Yudhiatara, \& Saehu. (2017). Mobile-assisted language learning (MALL) in Journal on English as a Foreign Language, 9(1), 87-106

Copyright (C) 2019 by JEFL, p-ISSN 2088-1657; e-ISSN 2502-6615 
Indonesian Islamic higher education. IJELTAL (Indonesian Journal of English Language Teaching and Applied Linguistics, 2(1), 21-31. https://doi.org http://dx.doi.org/10.21093/ijeltal.v2i1.52

Zhao, H., Sullivan, K. P. H., \& Mellenius, I. (2014). Participation, interaction and social presence: An exploratory study of collaboration in online peer review groups. British Journal of Educational Technology, 45(5), 807-819. https://doi.org/10.1111 bjet.12094

Zheng, B., \& Warschauer, M. (2015). Participation, interaction, and academic achievement in an online discussion environment. Computers and Education, 84, 78-89. https://doi.org/10.1016/..compedu.2015.01.008

\section{Authors' Brief CV}

Rully Agung Yudhiantara. He is a lecturer in the English Education Department, Faculty of Tarbiyah and Teacher Training, UIN Sunan Gunung Djati Bandung. His research interest is mainly on Mobile Assisted Language Learning (MALL).

Ade Yeti Nuryantini. She is a lecturer in Physics Education Department, Faculty of Tarbiyah and Teacher Training, UIN Sunan Gunung Djati Bandung. Her research interest includes mobile learning. 